\title{
AN ANALYTIC HIERARCHY PROCESS MODEL TO EVALUATE ROAD SECTION DESIGN
}

\author{
Danijela Barić, Hrvoje Pilko, Josip Strujić \\ Dept of Road Transport, Faculty of Transport and Traffic Sciences, University of Zagreb, Croatia \\ Submitted 26 November 2014; resubmitted 6 February 2015; accepted 27 March 2015; \\ first published online 30 March 2016
}

\begin{abstract}
The traffic system is as essential to modern society as the circulatory system to the human body. Road section design is therefore a key infrastructure activity for economic development, and multi-criteria decision-making can provide an interdisciplinary approach that moves beyond purely economic optimisation to include technological, technical and ecological factors. The present work describes applying the multi-criteria Analytical Hierarchy Process (AHP) method to evaluate road section design in an urban environment through differential weighting of various criteria and sub-criteria. The model is tested on a stretch of National Road D8 in the municipality of Podstrana near the city of Split (Croatia), which serves as an important route for commuters and tourists. The proposed AHP model provided reliable results that were robust to sensitivity analysis. This approach involving differential criterion weighting may prove useful for evaluating and selecting appropriate road section designs for this and other contexts.
\end{abstract}

Keywords: multi-criteria decision-making; analytic hierarchy process; road section design; intersection; roundabouts; sensitivity analysis.

\section{Introduction}

An efficient transport system is key to the economic and non-economic health of any country. Transport budgets are limited, so decision makers must select a subset of transportation projects for implementation. This involves trying to satisfy conflicting objectives measured in incommensurate units, the relative value of which involves political and moral dimensions, such as the value of a passenger hour or of human life (Avineri et al. 2000).

Multi-Criteria Decision-Making (MCDM) is well suited for dealing with the complexity of transportation project selection. It can help support the continuous planning and re-assessment necessary for optimising the use of available resources (Bendeković 2008) and deciding whether investment projects are reasonable and cost-effective. It can also take into account the social dimension of investment costs and benefits, which is critical for transportation projects of all sizes that have both social and economic impacts.

Numerous multi-criteria models have been applied to socially important investment projects, especially traffic infrastructure projects (Nowak 2005; Su et al. 2006; Barić et al. 2007; Aghdaie et al. 2012). These methods differ primarily in their optimisation criteria, which always involve a combination of technological, technical, ecological and other criteria. One of the most frequently used multi-criteria models is the Analytical Hierarchy Process (AHP) model (Podvezko 2009). The AHP model has proven valuable not just in traffic sciences (Saaty 1995) but also in most other spheres of human activity, including civil engineering (Cerić, Marić 2011; Cerić et al. 2013; Karleuša et al. 2014), marketing (Gholami, Seyyed-Esfahani 2012), entertainment (Vidal et al. 2011) and selection of academic staff (Rouyendegh, Erkan 2012).

Road section design is an essential part of traffic infrastructure projects in which sections of the same road may need to be designed with different characteristics to meet local needs or accommodate local constraints. Despite the key role of road section design in determining the success and final costs of transportation projects, few studies have attempted to use AHP to carry out and assess such designs. Therefore, we describe here a case study applying the AHP method to the reconstruction of a stretch of road in the municipality of Podstrana, a suburb outside the major city of Split (Croatia).

Corresponding author: Danijela Barić

E-mail: danijela.baric@fpz.hr 
The main purposes of this study were to:

- study, describe and analyse current applications of the AHP method in transport-related problems, with emphasis on road section design;

- assess the feasibility of applying the AHP method to optimise parameters for reconstructing a stretch of road and associated intersections;

- propose a specific AHP model for such reconstruction with the corresponding weighting factors for criteria and sub-criteria;

- apply and verify the proposed AHP model.

This study involved a thorough review of the relevant literature as well as the creation of a database intended to support future development and application of AHP procedures and methods.

The first section summarises previous studies of the AHP method and its application for solving transport-related problems. The second section describes the MCDM process and main characteristics of the AHP method. The third section describes the development and application of AHP structures for evaluating two alternative road section designs to reduce traffic congestion on a stretch of road in Croatia receiving significant commuter and tourist traffic. The last section discusses the results and draws final conclusions.

\section{Review of Previous Research}

The AHP method is increasingly important for solving transport-related problems (Abastante et al. 2012; Barić, Starčević 2015). While single-criterion and traditional cost-benefit analyses are still used in transport decisions, MCDM methods are increasingly replacing them (Barić et al. 2007). One well-studied method is the AHP method.

This method has been used most often in railway transport for planning railway routes (Barić et al. 2007) and optimising passenger transport (Sivilevičius, Maskeliūnaitè 2010). In air transport, it has been used most often for choosing the optimal means of transport (Yedla, Shrestha 2003) and optimising airport expansion (Vreeker et al. 2002). In logistics, the method has been applied most often to process optimisation (Poletan Jugović et al. 2007; Erkan, Can 2014) and selection of the optimal supply company at the national and international levels (Hashemkhani Zolfani et al. 2012). A small part of the literature has applied the AHP method to postal transport (Bošnjak et al. 2005) and maritime transport (Đelović, Medenica Mitrović 2010).

In road transport, the AHP method has been applied most often to decisions related to planning and investing in transport infrastructure (Holguín-Veras 1995; Klungboonkrong, Taylor 1999; López, Monzón 2010; Bottero et al. 2012; Wang et al. 2013), especially pavement maintenance (Tabucanon, Lee 1995; Wu et al. 2008; Farhan, Fwa 2009; Moazami et al. 2011; Sun, Gu 2011) and assessment of the safety of roads (Haghighat 2011; Wiethoff et al. 2012) and intersections (Basile et al. 2010). In urban settings, the AHP method has served most often to optimise transport planning in cities (Yu et al. 2011), selection of public garage locations (Deluka-Tibljaš et al. 2011), and public passenger transport (Jakimavičius, Burinskienè 2009; Chung et al. 2009). For evaluating sustainable urban mobility of cities, Campos proposed a procedure based on an index calculated through a weighted combination of multiple criteria (Campos 2009).

For the present study, the authors surveyed the literature for applications of the AHP method for resolving transport-related problems (Fig. 1). The following literature sources were searched for relevant studies:

- the scientific journals International Journal of the Analytic Hierarchy Process, Promet - Traffic \&Transportation and Transport;

- studies published through the International Symposium on the Analytic Hierarchy Process (ISAHP) conferences;

- doctoral dissertations and undergraduate theses performed at the Faculty of Transport and Traffic Sciences of the University of Zagreb (Croatia).

The International Journal of the Analytic Hierarchy Process was selected because of its primary purpose of publishing articles about MCDM based on AHP and the Analytical Network Process (ANP). The journal Promet - Traffic\&Transportation was selected because it is the leading transport journal in the country where the present study was carried out. The journal Transport was selected because it is internationally renowned for publishing high-quality traffic research. This literature survey showed that $13 \%$ of articles published over the past 5 years in International Journal of the Analytic Hierarchy Process applied the AHP method; the corresponding percentage in Promet - Traffic\&Transportation is $1 \%$ and in Transport - 3\%. The frequency with which the AHP method has been applied to various transport fields, based on analysis of studies published at ISAHP conferences, is shown in Fig. 1. The method has been applied most often to road transport problems (27\%), followed by rail transport (18\%) and air transport (14\%).

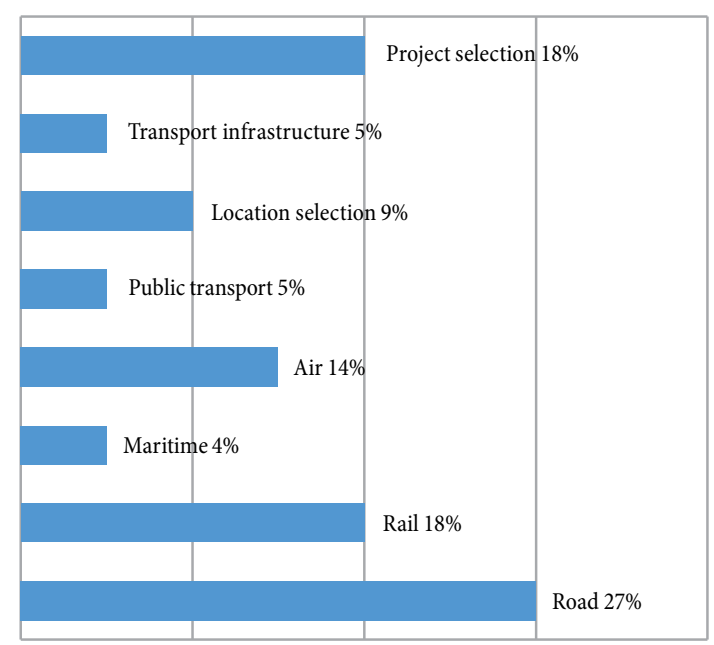

Fig. 1. Frequency with which the AHP method has been applied to different types of transport projects in the literature 
The method has also been applied often to prioritising transport projects $(18 \%)$ and selecting the locations of transport terminals (9\%). Less often, the method has been applied to selecting the optimal public transport system $(5 \%)$ or sustainable transport infrastructure (5\%), as well as to problems of maritime transport (4\%). Survey of undergraduate theses indicates that the AHP method has most often been applied to road transport, particularly for selecting the optimal design for reconstructing intersections.

Like other multi-criteria models, the AHP method is often implemented in conjunction with other methods, most frequently ANP, SWOT analysis, cost-benefit analysis and Fuzzy-AHP (FAHP). SWOT analysis allows strategic planning based on non-quantitative assessment of strengths, weaknesses, opportunities, and threats to the project. It is most often used for situational analysis as part of an organisation's marketing strategy. Recently the combination of AHP and SWOT has been used to analyse the implementation of Near-Field Communication (NFC) technology at Telecom Italia (Mehmood et al. 2014). In that work, the authors assessed negative and positive external and internal factors related to NFC adoption by the telecommunications industry. The resulting analysis is intended to help decision makers develop strategies for large-scale deployment.

Lately, the AHP method has been applied in conjunction with fuzzy-logic, termed FAHP. For example, Arslan (2009) presented a decision support model involving public involvement and oversight to help policy makers select transportation projects for implementation. The authors presented a set of 'if-then' rules based on Weber's psychophysical law of 1834 to translate fuzzy numbers into subjective preferences for pairs of alternatives. The AHP method was used to assign preferences to the alternatives. To demonstrate their procedure, the authors described how the method can be used to choose between a public bus route proposed by municipal authorities and another route proposed by private agencies.

Fouladgar et al. (2012) offered a new fuzzy multicriteria decision-making method, based on COmplex PRoportional ASsessment (COPRAS) and AHP, for evaluating asset maintenance strategies. FAHP was used to calculate the weights of evaluation criteria, and then alternatives were ranked based on fuzzy set theory and COPRAS. More recent studies have demonstrated various possible applications of FAHP and have compared it with the conventional AHP method (Erkan, Can 2014; Rossi et al. 2013). Studies have also validated a new method, called the Fuzzy-Based Evaluation Method (F-BEM), and shown its usefulness for evaluating the sustainability of alternative transport policies, such as to reduce pollution (Rossi et al. 2013).

Lin et al. (2008) have proposed an adaptive AHP approach $\left(\mathrm{A}^{3}\right)$ based on a soft computing scheme, namely Genetic Algorithms. The $\mathrm{A}^{3}$ approach is used to recover the real number weightings of the various AHP criteria and to generate a function for improving the Consistency Ratio (CR) of pairwise comparisons. Those authors validated the $\mathrm{A}^{3}$ approach by showing how it could be used to determine the weightings of the multiple criteria for a best-value bid in construction management. Those authors found the $\mathrm{A}^{3}$ method to lead to a cost-effective, faster and higher-quality decision than the traditional AHP method.

Our review of the literature indicates that the AHP method has been applied to all types of transport problems, but that few studies have applied it to the optimal choice of road section and/or intersection design. This gap in the literature was in large part the inspiration for the present work.

\section{Methodology}

MCDM involves optimising one or several objective functions, where the objective is defined as the condition of the system to be decided, over a defined set of possible solutions, corresponding to the various alternatives available to the system. The alternatives can differ in one of several attributes (criteria). Multi-criteria problems, in contrast to single-criterion problems, involve several objective functions and criterion functions.

Thomas Saaty developed the AHP method to guide complex decisions involving a large number of decision makers and criteria (Saaty 1995, 2008). It is one of the best-characterised and validated methods for MCDM. It can perform better than other multi-criteria methods because it can easily be adapted to different numbers of attributes (criteria) and alternatives, which can be described both quantitatively and qualitatively. Multicriteria analysis takes the following mathematical form:

$$
\max \left\{f_{1}(x), f_{2}(x), \ldots f_{n}(x), n \geq 2\right\}
$$

with the constraints:

$$
x \in A=\left[a_{1}, a_{2}, \ldots, a_{m}\right],
$$

where: $n$-number of criteria, $j=1,2, \ldots, n ; m$ - number of alternatives, $i=1,2, \ldots, m ; f_{j}$ - criteria, $j=1,2, \ldots, n$; $a_{i}$ - alternative for consideration, $i=1,2, \ldots, m ; A$ - set of all alternatives.

According to Saaty (2008), making a decision about priorities means decomposing the decision process into the following steps:

Define the problem and determine the kind of knowledge sought.

Structure the decision hierarchy from top to bottom as follows: the goal of the decision, followed by the objectives from a broad perspective, then criteria on which subsequent elements depend, and finally the set of alternatives.

Construct a set of pairwise comparison matrices. Each element in an upper level is compared with the elements in the level immediately below.

Use the priorities from the comparisons to weight the priorities in the level immediately below, and repeat this for every element. Then add together the weighted values for each element in the level below in order to obtain its overall or global priority. 
This process of weighting and adding should continue until the final priorities of the alternatives in the bottom level are obtained. In order to define the relative importance of criteria and sub-criteria with respect to the objective of research, criteria are ranked using a Saaty scale (Saaty 2008), which features five main levels of intensity ( 1 - equal importance, 3 - moderate importance, 5 - strong importance, 7 - very strong or demonstrated importance, 9 - extreme importance), as well as four intermediate levels ( 2 - weak or slight, 4 - moderate plus, 6 - strong plus, 8 - very, very strong).

The best alternative is selected based on the defined total weight priority vector by synthesising all weight vectors, and it is described by the following expression:

$$
W_{i}=\sum_{j=1}^{n} c_{j} w_{i j}, \forall i=1, \ldots, m,
$$

where: $W_{i}$ - weight, priority of alternative $i$; $c_{j}$ - weight of criterion $j(j=1,2, \ldots, n) ; w_{i j}$ - weight of alternative $i$ regarding criterion $j ; m$ - number of alternatives; $n$ number of criteria.

Saaty proved that for the consistent reciprocal matrix, the largest eigenvalue is equal to the number of comparisons, or $\lambda_{\max }=n$. Then he defined a measure of consistency, called the Consistency Index (CI), which indicates the deviation or degree of consistency using the following formula:

$$
C I=\frac{\lambda_{\max }-n}{n-1} \text {. }
$$

Saaty proposed that the CI should be compared with the corresponding random CI (RI). Saaty randomly generated reciprocal matrices using scale and calculated the RI to determine whether it was approximately $10 \%$ or less.

The CR compares the CI with RI:

$$
C R=\frac{C I}{R I} \text {. }
$$

If $\mathrm{CR}$ is smaller or equal to $10 \%$, the inconsistency is acceptable. If CR is greater than $10 \%$, the preference needs to be revised.

\section{Using the AHP to Evaluate Road Section Design}

\subsection{Definition of the Problem}

Many parameters must be taken into consideration when planning the reconstruction of road sections and corresponding intersections within a spatially restricted urban environment. This is particularly important when selecting the optimal alternative among various possibilities based on the most important parameters. The relative importance of the various parameters in this decision-making strongly depends on the type of problem and the perspective of the stakeholder. The relative weight of each factor can be defined through expert opinion based on surveys or panel discussions (Basile et al. 2010). Another possibility is to use the AHP method to weight the various factors, as one of us has pointed out (Strujić 2014). Here we apply this method to a particular case study.
The stretch of national road D8 from Poljička road to Put Starog sela road, $0.5 \mathrm{~km}$ long, lies in the municipality of Podstrana (population: 9129), a suburb to the southeast of the major city of Split (population: 178102). This stretch of road contains four level intersections (Fig. 2).

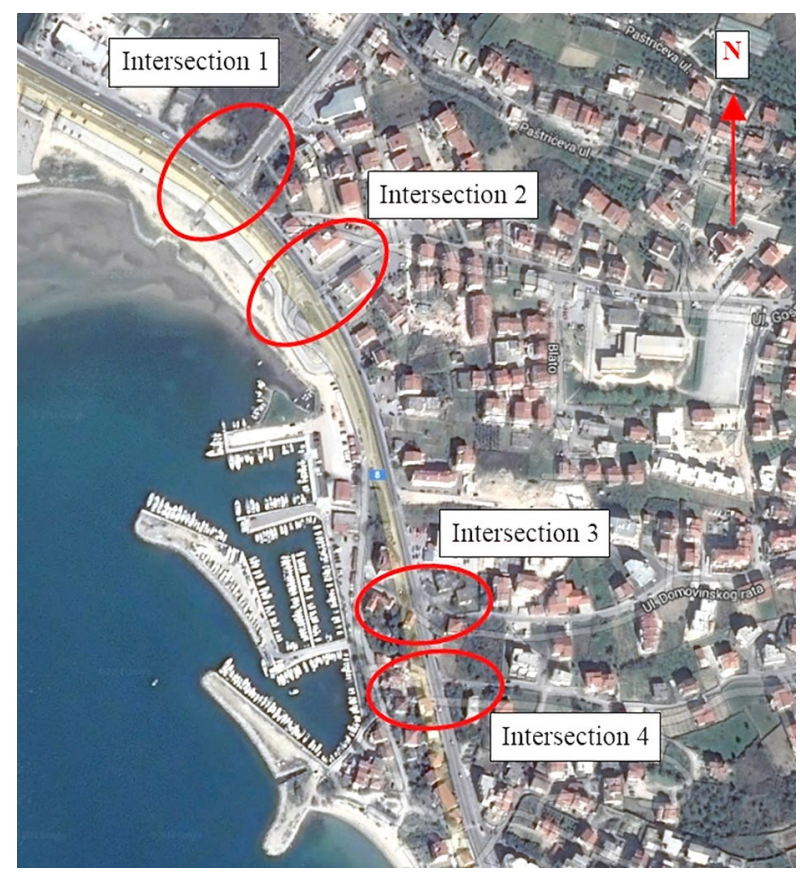

Fig. 2. Image of the stretch of national road D8 under investigation

The road stretch links the city of Split, which is the largest tourist destination in Dalmatia, with the smaller tourist city of Omiš to the east, the large tourist area on the Makarska Riviera and ultimately the tourist city of Dubrovnik. On the section of road extending from the direction of Split to the intersection of national road D8 and Poljička road, traffic runs in four lanes (two in each direction), and then in two lanes (one in each direction) after the intersection. Two partially signalised intersections (blinking yellow), labelled as intersection 1 (D8 Poljička road) and intersection 2 (D8 - Street Gospe od Siti-Jurasova road), lie $100 \mathrm{~m}$ apart. Two unsignalised intersections, labeled intersection 3 (D8 - Domovinskog rata street) and 4 (D8 - Put Starog sela road) lie $300 \mathrm{~m}$ away from intersections 1 and 2 .

Analysis of traffic flows along this stretch of road during morning and afternoon peak hours, when commuters are traveling between the suburb and Split, has shown significant traffic jams (Strujić 2014). This is particularly true on weekends during the summer tourist season. From intersection 1 the traffic pile-up can extend for 2-3 km, even up to $10 \mathrm{~km}$, causing delays of a few hours. In 2013, the traffic counter installed near intersection 1 recorded the highest average annual daily traffic (49443 vehicles) and the highest average summer daily traffic (57642 vehicles) of all counters installed in Croatia (Strujić 2014). 


\subsection{The AHP Model}

A theoretical framework for road section design (reconstruction) was defined including all relevant road design parameters extracted from the research literature and university textbooks on road and civil engineering design. These parameters constituted five criteria and associated sub-criteria (Fig. 3) that were used to evaluate two alternative reconstructions of the D8 stretch indicated in Fig. 2. Our choice of criteria and sub-criteria was also based on insights into modeling and optimising intersections (Legac 2008) and other studies (Barić et al. 2007; Pilko 2014; Barišić 2014). The perspective adopted in our AHP model was that of the road traffic engineer.

Although Legac (2008) highlights the significance of all criteria and sub-criteria as well as their correlations, the present authors have shown that they can be divided structurally and conceptually (Barić et al. 2007; Pilko 2014; Barišić 2014). Transport-Technical-Technological (TTT) criteria were derived from fundamental transport-construction criteria reflecting micro and macro aspects of modeling intersections. Some TTT sub-criteria were based on previous studies, i.e. design speed (Šurdonja et al. 2013; Pilko et al. 2014) and spatio-urban impact (Basile et al. 2010; Barišić 2014). The remaining four criteria and their associated subcriteria reflected primarily studies by one of us (Pilko 2014) and analysis of functional efficiency and costs (Mauro, Cattani 2012). The sub-criterion of number of conflict points was selected based on research by one of us (Strujić 2014).

We collected and analysed data from a survey of 61 road traffic engineers (Pilko 2014) in order to generate weighting functions for objectives, criteria and alternatives based on the Saaty scale. Criteria weighting is reported in that study in detail. The results of that survey represent the consensus assessment of all the experts surveyed, and this assessment was used to develop the AHP model. After criteria were selected, analysed and ranked, data were entered and processed in the software Expert Choice 11.5.

The highest weighting coefficient $(0.286)$ was associated with the criterion Functional efficiency (EF), while the lowest coefficient $(0.115)$ was associated with the criterion Ecological (ECO). The low inconsistency among observed criteria (0.03) suggested a well-structured model as shown in Table.

Table. Criteria priorities

\begin{tabular}{|l|c|}
\hline \multicolumn{1}{|c|}{ Criteria } & $\begin{array}{c}\text { Criteria weights } \\
\text { (priorities) }\end{array}$ \\
\hline Functional efficiency & 0.286 \\
\hline Traffic-Technical-Technological & 0.245 \\
\hline Safety & 0.211 \\
\hline Cost & 0.143 \\
\hline Ecological & 0.115 \\
\hline Inconsistency $=0.03$ \\
\hline
\end{tabular}

\subsection{Results of the AHP Method}

Assessment of sub-criteria and proposed alternatives was also carried out using Expert Choice 11.5. The two alternatives were as follows (Strujić 2014). The first alternative, called Variant 1 (V1), involved introducing and coordinating signaling at intersections 1 (D8 - Poljička road) and 2 (D8 - Street Gospe od Siti-Jurasova road), as well as adding a traffic lane for turning left from main road D8 at intersections 3 (D8 - Domovinskog rata Street) and 4 (D8 - Put starog sela road). The second alternative, called Variant 2 (V2), involved converting intersection 1 into a roundabout and closing intersec-

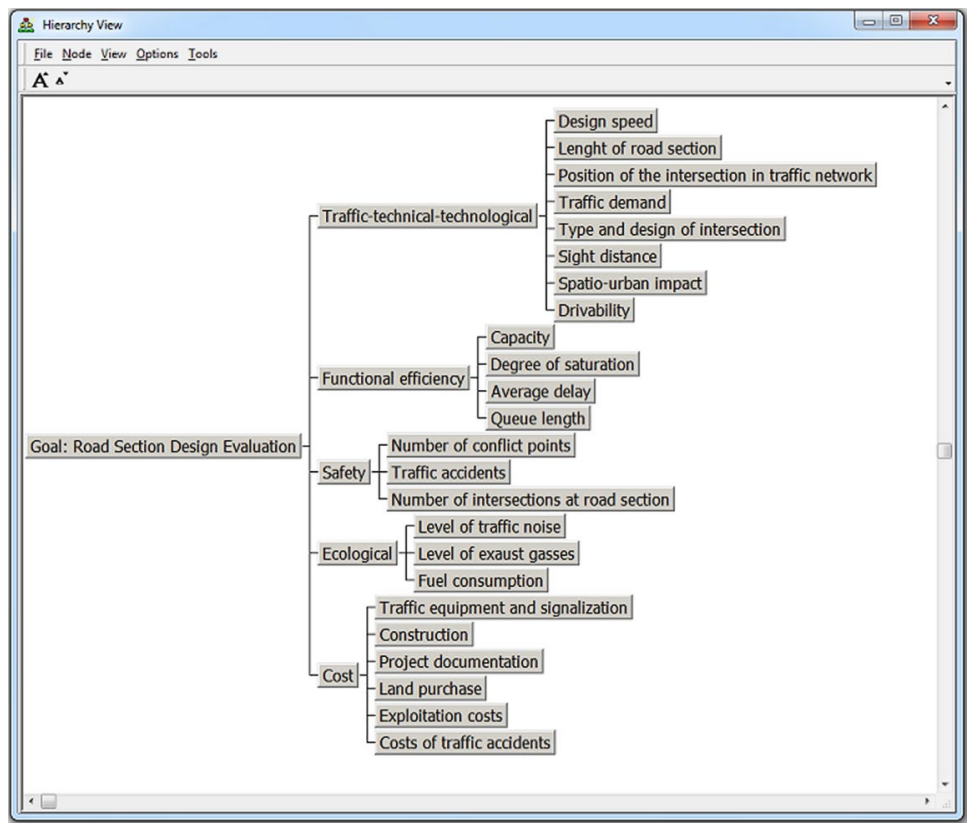

Fig. 3. Hierarchy structure of the AHP model 
tion 2. In this alternative, intersection 1 would feature on its south-eastern side three new approaches from Gospe od Siti street, D8 - Omiš and Jurasova street. Intersection 3 would also be closed, and Domovinskog rata street would be connected via by-pass with Put Staroga sela street. Finally, an extra lane for left turns would be added to intersection 4 .

In the determination of the importance of TTT criteria, the highest weighting coefficient (0.182) was assigned to the sub-criterion Length of road section, and the smallest weighting coefficient $(0.055)$ to the subcriterion Spatio-urban impact. Overall CR of the model was $6 \%$, which is below the cut-off of $10 \%$ (section 2 ), indicating a well-structured model.

In determining functional efficiency, the sub-criterion Capacity received the highest weighting coefficient (0.486) and the sub-criterion Queue length the lowest (0.095). Overall CR of the model was $0.299 \%$, again indicating a well-structured model. During assessment of traffic safety, all three sub-criteria were found to be correlated and therefore were ranked as equally important. For this reason, total inconsistency of the model was $0 \%$.

In the determination of ecological impact, the subcriterion Level of exhaust gases was assigned the highest weighting coefficient (0.500), and the sub-criterion Level of traffic noise the lowest (0.167). Overall model CR was $0 \%$.

In the determination of costs, the sub-criterion Construction cost received the highest weighting coefficient (0.296) and the sub-criterion Traffic equipment and signalisation cost the lowest (0.056). Overall model CR was $0.504 \%$. The results of the AHP modelling, together with weighting of all criteria and sub-criteria, are shown in Fig. 4.

\subsection{Sensitivity Analysis}

It can be difficult to assess the efficiency of a transport infrastructure investment because cost-benefit analyses conducted before the project may not accurately reflect what will happen over the 10- to 30-year lifespan of the investment. Hence, it can be useful to perform sensitivity analysis, which assesses investment efficiency as a function of input values for individual parameters. In this way, the stakeholder can determine whether the project is acceptable even if certain critical parameters deviate from their expected values. Critical parameters are those that can significantly affect the overall efficiency of the project and can change over the project's lifespan.

Sensitivity analysis is reasonably straightforward within the AHP method. Changing priorities of the elements on higher levels influences the final results more than changing the priorities of lower level elements. Therefore, we altered the weights of various criteria and tested how the changes affected the recommended alternative for road section reconstruction.

Only the criterion Cost gave higher priority to Variant 1 (Fig. 5). Systematically changing the weighting for Cost showed that Variant 1 gained the advantage over Variant 2 only when the weighting was increased from 0.143 to at least 0.584 (Fig. 6)

\section{Discussion and Conclusions}

Using the AHP method to assess a large number of alternatives on the basis of comprehensive parameters can significantly improve the quality of decision-making about investments in transport infrastructure. Here we report one case study suggesting that the AHP method can work well for choosing the optimal design (recon-

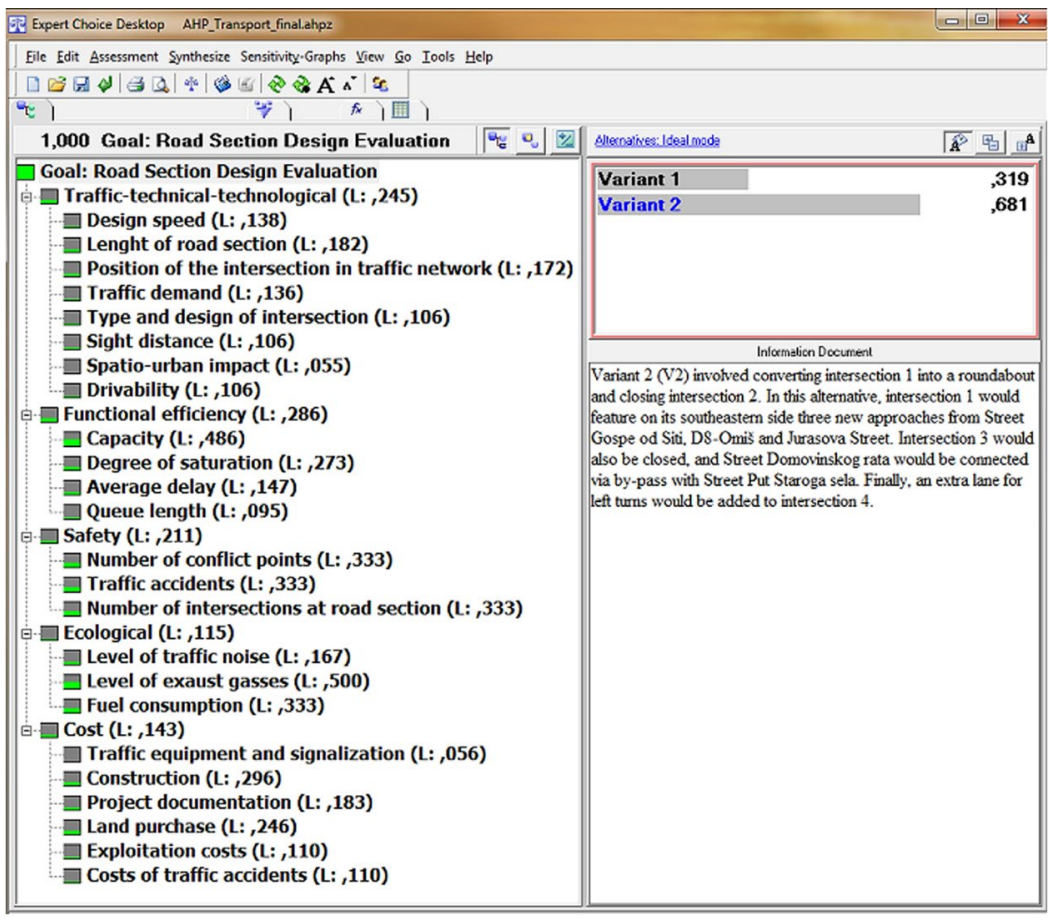

Fig. 4. Weighting factors for criteria and sub-criteria in the AHP model 


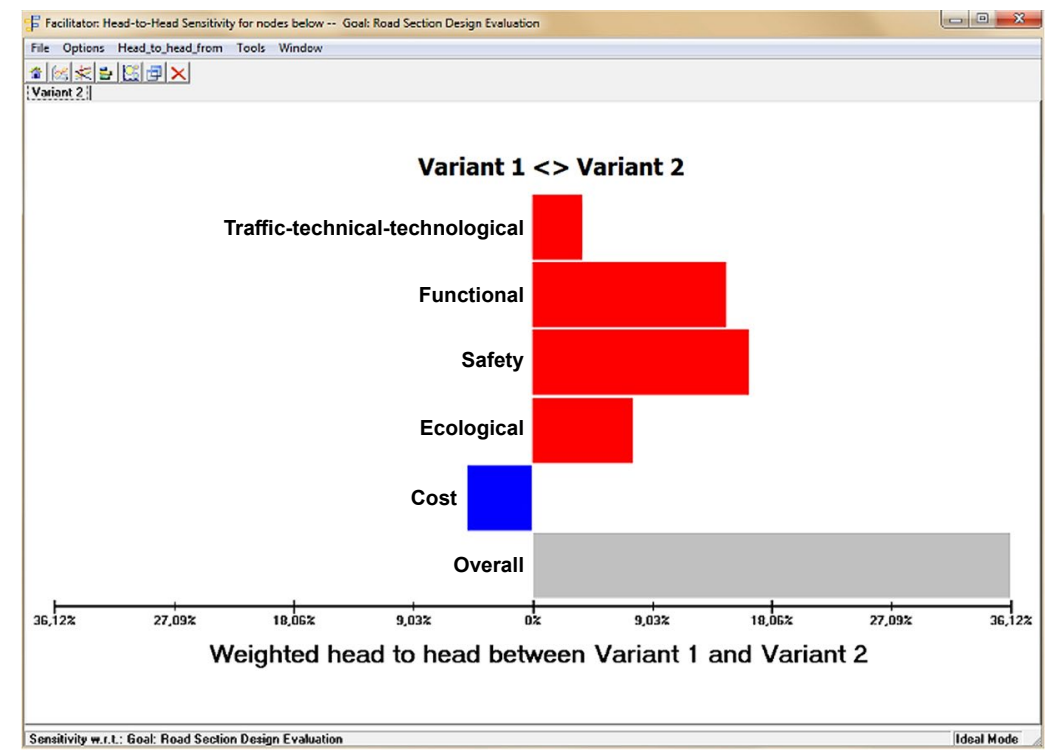

Fig. 5. Priority of alternatives for different criteria depicted using a head-to-head graph

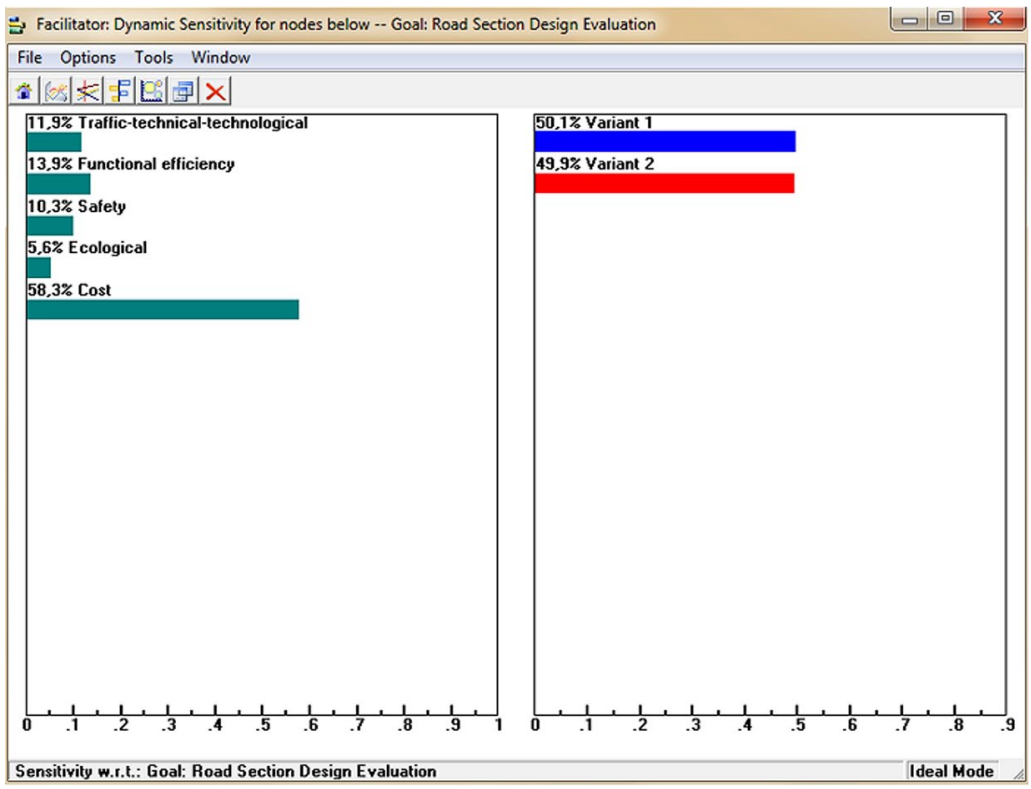

Fig. 6. Sensitivity of the recommended alternative to changes in the weighting of the criterion Cost, depicted using a dynamic graph

struction) of a road section in an urban area. This is the first such use of the AHP method, extending previous studies showing that the AHP method also works well in several other types of transport-related problems.

Of the 5 criteria selected for the AHP model, the most important was Functional efficiency, and the least important was Ecological. Inconsistency among the observed criteria was 0.03 , indicating that the model was well structured. Inconsistency was similarly low for AHP structures of sub-criteria, among which Length of road section, Capacity, Level of exhaust gases and Construction cost were most important, while Spatiourban impact, Queue length, Level of traffic noise and Traffic equipment and signalisation costs were least important.
Variant 2 proved to be an optimal design solution, and sensitivity analysis showed this result to be robust, affected only by a large increase in the weighting of the criterion Cost.

Since this study is the first to our knowledge to apply the AHP method to road section design, it is difficult to compare our results with others in the literature. Therefore, further work is needed to confirm the validity of our approach. One thing to note is that the study area sees significant traffic during business commuting hours as well as during the summer due to large tourism flows. Future studies should examine whether our approach works in urban areas with other traffic dynamics. We expect our choice of parameters can capture a reasonable range of situations, since we selected them 
from the literature and a field survey of 61 road design experts in Croatia. Our parameters combined the factors most frequently used to evaluate projects, such as cost, safety, and ecological and social impact (Sivilevičius, Maskeliūnaitè 2010; Teng et al. 2010; López, Monzón 2010; Deluka-Tibljaš et al. 2011; Abastante et al. 2012) together with traffic-focused parameters, i.e. TTT and functional efficiency criteria. While these traffic-focused parameters may limit the generalisability of our AHP model, it may be possible to supplement them with construction-related ones, such as configuration of the terrain, available surface, and horizontal and vertical elements (Legac 2008; Monajjem et al. 2013).

This study featured several limitations. One was that our data on the number and movements of traffic flow in the study area turned out to be inadequate for assessing functional efficiency or level of service, preventing us from simulating micro and macro aspects of traffic movements and flow using such tools as PTV Visum. Future studies should address these issues.

Future work should also conduct a survey of road traffic engineering experts from outside Croatia and consider perspectives of other stakeholders, such as civil engineer, economist, ecologist, or urban planner. This input may significantly alter the choice and weighting of criteria and sub-criteria, which may affect the recommended road section design.

It is also possible that combining our AHP method with other MCDM models may improve its performance, versatility or robustness. Models that may complement AHP include ANP (Cerić et al. 2013), SWOT (Mehmood et al. 2014), FAHP (Avineri et al. 2000; Arslan 2009; Karleuša et al. 2014) and COPRAS-G (Aghdaie et al. 2012).

The proposed AHP model with its criteria weighting structure may help policy makers select appropriate road section design projects for implementation. The model and the associated database may prove a useful and adaptable tool for dealing with a variety of problems.

\section{Acknowledgements}

The research described in this paper was conducted within the scope of the research project 'Correlation between Design and Safety at Roundabouts' (No. 1350000000-3313), funded by the Ministry of Science, Education and Sports of the Republic of Croatia.

\section{References}

Abastante, F.; Bottero, M.; Lami, I. M. 2012. Using the analytic network process for addressing a transport decision problem, International Journal of the Analytic Hierarchy Process 4(1): 41-60. http://dx.doi.org/10.13033/ijahp.v4i1.119

Aghdaie, M. H.; Hashemkhani Zolfani, S.; Zavadskas, E. K. 2012. Prioritizing constructing projects of municipalities based on AHP and COPRAS-G: a case study about footbridges in Iran, The Baltic Journal of Road and Bridge Engineering 7(2): 145-153.

http://dx.doi.org/10.3846/bjrbe.2012.20
Arslan, T. 2009. A hybrid model of fuzzy and AHP for handling public assessments on transportation projects, Transportation 36(1): 97-112.

http://dx.doi.org/10.1007/s11116-008-9181-9

Avineri, E.; Prashker, J.; Ceder, A. 2000. Transportation projects selection process using fuzzy sets theory, Fuzzy Sets and Systems 116(1): 35-47. http://dx.doi.org/10.1016/S0165-0114(99)00036-6

Barić, D.; Čerepić, D.; Radačić, Ž. 2007. Implementation of relevant methods in assessing traffic-technological projects, Promet - Traffic\&Transportation 19(5): 329-336.

Barić, D.; Starčević, M. 2015. Implementation of analytic hierarchy process in solving transport problems, International Journal of the Analytic Hierarchy Process 7(2): 295-312. http://dx.doi.org/10.13033/ijahp.v7i2.251

Barišić, I. 2014. Urbanistički parametri pri planiranju kružnih raskrižja: doktorska disertacija. Sveučilišta u Zagrebu. $206 \mathrm{~s}$. (in Croatian).

Basile, O.; Persia, L.; Usami, D. S. 2010. A methodology to assess pedestrian crossing safety, European Transport Research Review 2(3): 129-137. http://dx.doi.org/10.1007/s12544-010-0036-z

Bendeković, J. 2008. Analiza i struktura investicijskih projekata, Računovodstvo, revizija i financije 18(4): 76-82 (in Croatian).

Bošnjak, I.; Kavran, Z.; Matijević, D. 2005. Design of delivery areas of public postal operator by applying AHP model, Promet - Traffic\&Transportation 17(2): 77-85.

Bottero, M.; Ferretti, V.; Pomarico, S. 2012. Assessing the sustainability of alternative transport infrastructures, International Journal of the Analytic Hierarchy Process 4(1): 61-77. http://dx.doi.org/10.13033/ijahp.v4i1.101

Campos, V. B. G.; Ramos, R. A. R. 2009. Multi-criteria analysis procedure for sustainable mobility evaluation in urban areas, Journal of Advanced Transportation 43(4): 371-390. http://dx.doi.org/10.1002/atr.5670430403

Cerić, A.; Marčić, D.; Kovačević, M. S. 2013. Applying the analytic network process for risk assessment in sustainable ground improvement, Gradevinar 65(10): 919-929.

Cerić, A.; Marić, T. 2011. Determining priorities for managing risk on construction projects, Gradevinar 63(3): 265-271.

Chung, M.-C.; Wei, C.-H.; Chen, C.-J. 2009. Hierarchical evaluation scheme on technology sourcing for advanced public transport systems, Journal of Advanced Transportation 43(1): 89-111. http://dx.doi.org/10.1002/atr.5670430106

Deluka-Tibljaš, A.; Karleuša, B.; Benac, Č. 2011. AHP methodology application in garage-parking facility location selection, Promet - Traffic\&Transportation 23(4): 303-313. http://dx.doi.org/10.7307/ptt.v23i4.133

Đelović, D.; Medenica Mitrović, D. 2010. An approach to the selection of optimal transformation strategy in seaports, Promet - Traffic\&Transportation 22(3): 219-228. http://dx.doi.org/10.7307/ptt.v22i3.278

Erkan, T. E.; Can, G. F. 2014. Selecting the best warehouse data collecting system by using AHP and FAHP methods, Tehnički vjesnik - Technical Gazette 21(1): 87-93.

Farhan, J.; Fwa, T. 2009. Pavement maintenance prioritization using analytic hierarchy process, Transportation Research Record: Journal of the Transportation Research Board 2093: 12-24. http://dx.doi.org/10.3141/2093-02

Fouladgar, M. M.; Yazdani-Chamzini, A.; Lashgari, A.; Zavadskas, E. K.; Turskis, Z. 2012. Maintenance strategy selection using AHP and COPRAS under fuzzy environment, International Journal of Strategic Property Management 16(1): 85-104. http://dx.doi.org/10.3846/1648715X.2012.666657 
Gholami, M. H.; Seyyed-Esfahani, M. 2012. An integrated framework for competitive market strategy selection by using fuzzy AHP, Tehnički vjesnik - Technical Gazette 19(4): 769-780.

Haghighat, F. 2011. Application of a multi-criteria approach to road safety evaluation in the Bushehr province, Iran, Promet - Traffic\&Transportation 23(5): 341-352. http://dx.doi.org/10.7307/ptt.v23i5.152

Hashemkhani Zolfani, S.; Chen, I.-S.; Rezaeiniya, N.; Tamošaitienè, J. 2012. A hybrid MCDM model encompassing AHP and COPRAS-G methods for selecting company supplier in Iran, Technological and Economic Development of Economy 18(3): 529-543.

http://dx.doi.org/10.3846/20294913.2012.709472

Holguín-Veras, J. 1995. Comparative assessment of AHP and MAV in highway planning: case study, Journal of Transportation Engineering 121(2): 191-200.

http://dx.doi.org/10.1061/(ASCE)0733-947X(1995)121:2(191)

Jakimavičius, M.; Burinskienè, M. 2009. Assessment of Vilnius city development scenarios based on transport system modelling and multicriteria analysis, Journal of Civil Engineering and Management 15(4): 361-368.

http://dx.doi.org/10.3846/1392-3730.2009.15.361-368

Karleuša, B.; Ožanić, N.; Deluka-Tibljaš, A. 2014. Improving decision making in defining priorities for implementation of irrigation plans using AHP methodology, Tehnički vjesnik - Technical Gazette 21(3): 673-680.

Klungboonkrong, P.; Taylor, M. A. P. 1999. An integrated planning tool for evaluating road environmental impacts, Computer-Aided Civil and Infrastructure Engineering 14(5): 335-345. http://dx.doi.org/10.1111/0885-9507.00152

Legac, I. 2008. Raskrižja javnih cesta - cestovne prometnice II. Sveučilišta u Zagrebu. 205 s. (in Croatian).

Lin, C.-C.; Wang, W.-C.; Yu, W.-D. 2008. Improving AHP for construction with an adaptive AHP approach $\left(\mathrm{A}^{3}\right)$, Automation in Construction 17(2): 180-187.

http://dx.doi.org/10.1016/j.autcon.2007.03.004

López, E.; Monzón, A. 2010. Integration of sustainability issues in strategic transportation planning: a multi-criteria model for the assessment of transport infrastructure plans, Computer-Aided Civil and Infrastructure Engineering 25(6): 440451. http://dx.doi.org/10.1111/j.1467-8667.2010.00652.x

Mauro, R.; Cattani, M. 2012. Functional and economic evaluations for choosing road intersection layout, Promet Traffic\&Transportation 24(5): 441-448.

http://dx.doi.org/10.7307/ptt.v24i5.1180

Mehmood, F.; Hassannezhad, M.; Abbas, T. 2014. Analytical investigation of mobile NFC adaption with SWOT-AHP approach: a case of Italian telecom, Procedia Technology 12: 535-541. http://dx.doi.org/10.1016/j.protcy.2013.12.526

Moazami, D.; Behbahani, H.; Muniandy, R. 2011. Pavement rehabilitation and maintenance prioritization of urban roads using fuzzy logic, Expert Systems with Applications 38(10): 12869-12879. http://dx.doi.org/10.1016/j.eswa.2011.04.079

Monajjem, M. S.; Jalal Kamali, M. H.; Ayubirad, M. S. 2013. Studying the effect of spiral curves and intersection angle, on the accident ratios in two-lane rural highways in Iran, Promet - Traffic\&Transportation 25(4): 343-348. http://dx.doi.org/10.7307/ptt.v25i4.332

Nowak, M. 2005. Investment projects evaluation by simulation and multiple criteria decision aiding procedure, Journal of Civil Engineering and Management 11(3): 193-202. http://dx.doi.org/10.1080/13923730.2005.9636350
Pilko, H. 2014. Optimiziranje oblikovne i sigurnosne komponente raskrižja s kružnim tokom prometa: doktorska disertacija. Sveučilišta u Zagrebu. 194 s. (in Croatian).

Pilko, H.; Brčić, D.; Šubić, N. 2014. Study of vehicle speed in the design of roundabouts, Gradevinar 66(5): 407-416. http://dx.doi.org/10.14256/JCE.887.2013

Podvezko, V. 2009. Application of AHP technique, Journal of Business Economics and Management 10(2): 181-189. http://dx.doi.org/10.3846/1611-1699.2009.10.181-189

Poletan Jugović, T.; Jugović, A.; Zelenika, R. 2007. Multicriteria optimisation in logistics forwarder activities, Promet Traffic\&Transportation 19(3): 145-153.

Rossi, R.; Gastaldi, M.; Gecchele, G. 2013. Comparison of fuzzy-based and AHP methods in sustainability evaluation: a case of traffic pollution-reducing policies, European Transport Research Review 5(1): 11-26. http://dx.doi.org/10.1007/s12544-012-0086-5

Rouyendegh, B. D.; Erkan, T. E. 2012. Selection of academic staff using the fuzzy analytic hierarchy process (FAHP): a pilot study, Tehnički vjesnik - Technical Gazette 19(4): 923-929.

Saaty, T. L. 2008. Decision making with the analytic hierarchy process, International Journal of Services Sciences 1(1): 83-98. http://dx.doi.org/10.1504/IJSSCI.2008.017590

Saaty, T. L. 1995. Transport planning with multiple criteria: the analytic hierarchy process applications and progress review, Journal of Advanced Transportation 29(1): 81-126. http://dx.doi.org/10.1002/atr.5670290109

Sivilevičius, H.; Maskeliūnaitè, L. 2010. The criteria for identifying the quality of passengers' transportation by railway and their ranking using AHP method, Transport 25(4): 368-381. http://dx.doi.org/10.3846/transport.2010.46

Strujić, J. 2014. Vrednovanje mogućih rješenja rekonstrukcije državne ceste D8 na dionici od Poljičke ceste do ulice Put Starog sela primjenom AHP metode: magisterska rabota. Sveučilišta u Zagrebu. (in Croatian).

Su, C.-W.; Cheng, M.-Y.; Lin, F.-B. 2006. Simulation-enhanced approach for ranking major transport projects, Journal of Civil Engineering and Management 12(4): 285-291.

Sun, L.; Gu, W. 2011. Pavement condition assessment using fuzzy logic theory and analytic hierarchy process, Journal of Transportation Engineering 137(9): 648-655. http://dx.doi.org/10.1061/(ASCE)TE.1943-5436.0000239

Šurdonja, S.; Deluka-Tibljaš, A.; Babić, S. 2013. Optimization of roundabout design elements, Tehnički vjesnik - Technical Gazette 20(3): 533-539.

Tabucanon, M. T.; Lee, H.-M. 1995. Multiple criteria evaluation of transportation system improvement projects: the case of Korea, Journal of Advanced Transportation 29(1): 127-143. http://dx.doi.org/10.1002/atr.5670290110

Teng, J.-Y.; Huang, W.-C.; Lin, M.-C. 2010. Systematic budget allocation for transportation construction projects: a case in Taiwan, Transportation 37(2): 331-361. http://dx.doi.org/10.1007/s11116-009-9239-3

Vidal, L.-A.; Marle, F.; Bocquet, J.-C. 2011. Using a Delphi process and the analytic hierarchy process (AHP) to evaluate the complexity of projects, Expert Systems with Applications 38(5): 5388-5405. http://dx.doi.org/10.1016/j.eswa.2010.10.016

Vreeker, R.; Nijkamp, P.; Ter Welle, C. 2002. A multicriteria decision support methodology for evaluating airport expansion plans, Transportation Research Part D: Transport and Environment 7(1): 27-47. http://dx.doi.org/10.1016/S0969-6997(01)00005-9 
Wang, W.-C.; Yu, W.-D.; Yang, I.-T.; Lin, C.-C.; Lee M.-T.; Cheng, Y.-Y. 2013. Applying the AHP to support the bestvalue contractor selection - lessons learned from two case studies in Taiwan, Journal of Civil Engineering and Management 19(1): 24-36. http://dx.doi.org/10.3846/13923730.2012.734851

Wiethoff, M.; Brookhuis, K.; De Waard, D.; Marchau, V.; Walta, L.; Wenzel, G.; De Brucker, K.; Macharis, C. 2012. A methodology for improving road safety by novel infrastructural and invehicle technology combinations, European Transport Research Review 4(2): 67-77.

http://dx.doi.org/10.1007/s12544-011-0065-2

Wu, Z.; Flintsch, G.; Chowdhury, T. 2008. Hybrid multiobjective optimization model for regional pavement-preservation resource allocation, Transportation Research Record: Journal of the Transportation Research Board 2084: 28-37. http://dx.doi.org/10.3141/2084-04

Yedla, S.; Shrestha, R. M. 2003. Multi-criteria approach for the selection of alternative options for environmentally sustainable transport system in Delhi, Transportation Research Part A: Policy and Practice 37(8): 717-729. http://dx.doi.org/10.1016/S0965-8564(03)00027-2

Yu, J.; Liu, Y.; Chang, G.-L.; Ma, W.; Yang, X. 2011. Locating urban transit hubs: multicriteria model and case study in China, Journal of Transportation Engineering 137(12): 944-952.

http://dx.doi.org/10.1061/(ASCE)TE.1943-5436.0000275 